\title{
Adventitious Root Formation in Stem Cuttings of Quercus bicolor and Quercus macrocarpa and Its Relationship to Stem Anatomy
}

\author{
J. Naalamle Amissah", Dominick J. Paolillo Jr. ${ }^{2}$, and Nina Bassuk ${ }^{3,4}$ \\ Department of Horticulture, 134A Plant Science Building, Cornell University, Ithaca, NY 14853
}

\begin{abstract}
AdDitional INDEX wORDs. oaks, parenchyma gaps, propagation, rooting, sclerenchyma
Abstract. This study investigated the relationship of stem anatomy to differences in rooting ability between $Q u e r c u s$ bicolor Wild. and Quercus macrocarpa Michx. cuttings. Quercus bicolor cuttings were found to have a significantly greater proportion of parenchymatous gaps in the sclerenchyma sheath over a 9-week period compared with $Q$. macrocarpa cuttings. In $Q$. macrocarpa, the percentage gap was generally low, coinciding with the low percentage rooting observed in this species. Percentage rooting correlated well $\left(r^{2}=0.75\right)$ with the percentage parenchymatous gap in the perivascular region of $Q$. bicolor cuttings. The problems with accepting this relationship as causal are stated in the discussion. Untreated cuttings showed normal stem organization: a dermal tissue system that included the initial stages of phellem formation, a cortex, and a ring of closely arranged vascular bundles in early stages of secondary growth. The locations of the five distinct lobes of the pith were coordinated with the locations of root primordia. Callus growth was first detected in the cortex (i.e., external to the fiber bundles), followed by proliferation within the phloem, opposite the lobes of the pith, 8 to 12 days after cuttings were treated with indole butyric acid (6000 $\mathrm{mg} \cdot \mathrm{L}^{-1}$ dissolved in $50 \% \mathrm{v} / \mathrm{v}$ ethanol in water). By 14 to 16 days, root primordia had developed within the proliferative tissue in the secondary phloem. In both species, root primordia penetrated parenchymatous gaps in the fiber sheath directly, the fiber bundles being displaced laterally as the roots increased in size.
\end{abstract}

Oaks (Quercus L.) are among the most important hardwood species in North America. Unfortunately, due to difficulty in vegetative propagation, hybrids and unique types of oaks are rarely introduced into the nursery trade. Poor rooting ability among plant species has been attributed to the presence of growth inhibitors (Barlow et al., 1961; Ooyama, 1962), a lack of or imbalance of hormones or rooting cofactors (Hess, 1961; Raviv et al., 1986), and the presence of physical barriers (Beakbane, 1961; Edwards and Thomas, 1980). Several anatomical studies have suggested a correlation between difficulty in rooting and the presence of a pericyclic sclerenchyma layer (Beakbane, 1961, 1969; Ciampi and Gellini, 1958; Edwards and Thomas, 1980; Goodin, 1965). Beakbane (1969) and Edwards and Thomas (1980) suggested that the presence of a continuous sclerenchyma layer might act as a physiological barrier to adventitious root initiation or as a mechanical barrier to root emergence. Roots arising from the cambium and phloem regions in Vaccinium corymbosum L. hardwood cuttings were reportedly impeded by a continuous layer of lignified pericyclic fibers and by the epidermis (Mahlstede and Watson, 1952). In some instances, a developing primordium was found to bend at right angles before emerging through gaps in the sclerenchyma sheath. Similar observations were made in Dianthus caryophyllus L. (Stangler, 1956) and Coffea robusta L. Linden (Reańo, 1940), where root primordia grew down inside the fiber sheath and emerged through the base of the cutting. Beakbane (1961) found that rooting was inversely proportional to the percentage of fibers and the integrity of the sclerenchyma

Received for publication 17 Jan. 2008. Accepted for publication 1 Apr. 2008. ${ }^{1}$ Graduate student.

${ }^{2}$ Professor Emeritus of Plant Biology.

${ }^{3}$ Professor of Horticulture.

${ }^{4}$ Corresponding author. E-mail: nlb2@cornell.edu. ring in pear (Pyrus communis L.), beech (Fagus sylvatica L.), and apple (Malus Mill.) rootstocks.

In contrast, Davies et al. (1982) were unable to find a relationship between the presence of a sclerenchyma sheath and root formation in mature and juvenile leaf bud cuttings of Ficus pumila $\mathrm{L}$. They concluded that the differences in rooting capabilities were more related to the ease of root initiation rather than restrictions by the sclerenchyma tissue.

The density of occurrence of sclerenchymatous cells in the cortex of Populus tremuloides Michx. cuttings was found to increase with tree age (Hicks and Gladstone, 1971). When subject to favorable rooting conditions, cuttings from mature tree age classes failed to form root primordia, whereas those from juvenile root suckers succeeded. Lovell and White (1984) saw the prevention of an initial phase of cambial activation in mature Griselina littoralis Raoul. and Griselina lucida G. Forst. cuttings as a more likely factor accounting for poor rooting rather than the presence of a sclerenchyma sheath. William et al. (1984) found no correlation between stem sclerification and poor root formation, but instead associated poor rooting with the suberization of tissue in the cortex. Sachs et al. (1964) found no relationship between ease of rooting and the density and continuity of the sclerenchyma layer in stem cuttings of cherry (Prunus L.), pear, and olive (Olea europaea L.) cultivars. They noted substantial cell expansion and proliferation in the cortex, phloem, and cambium that were enough to cause breaks in the continuous sheath of sclerenchyma tissue.

Etiolation as a pretreatment has been useful in improving rooting in a number of woody plant species. Some anatomical changes associated with etiolation are delayed lignification of pericyclic cells (Priestley, 1926; Reid, 1923; Stoutemeyer, 1961), the presence of undifferentiated parenchyma in root initiation sites (Herman and Hess, 1963), and softer tissues, especially in the pith and fibers (Smith, 1924). Maynard and 
Bassuk (1992) reported a delay in sclereid formation by up to 3 months in Carpinus betulus L. that correlated well with increased rooting potential in etiolated cuttings.

In spite of results that seem to disqualify the sclerenchyma ring as a barrier to the emergence of adventitious roots, it is a known fact that where extensive sclerification takes place within the cortex, rooting generally does not occur (Maynard and Bassuk, 1996; White and Lovell, 1984). However, it is evident from the literature that the relationship between the sclerenchyma sheath and rooting ability in plants has, to a large extent, been based on visual impressions. One objective of this study was to quantify differences in the extent of fiber-free gaps in $Q$. bicolor and $Q$. macrocarpa as stems used to furnish cuttings aged over a 9-week period. Additional objectives included identifying the site(s) of primordia initiation and recording the progress of adventitious root formation with a view to establishing whether the sclerenchyma ring can be interpreted as a barrier to the initiation and emergence of adventitious roots.

\section{Materials and Methods}

Handling of Stock plants and taking of Cuttings. All stock plants were grown from seed. Dormant 8-year-old fieldgrown $Q$. bicolor (175 stock plants) and Q. macrocarpa $(252$ stock plants) were used in Expt. 1. They were cut back, leaving a 4-cm-tall stump above the soil surface. For Expt. 2, dormant containerized plants were grown in 2 parts perlite-to- 1 part peat (by volume) in containers of 11.4-L volume, fed with slowrelease fertilizer, hand weeded, and maintained without repotting for several years. Roots were not pruned. Plants of $Q$. bicolor (310 stock plants) and Q. macrocarpa (210 stock plants) were brought into a warm greenhouse $\left(23.9^{\circ} \mathrm{C}\right.$ day/ $18.3{ }^{\circ} \mathrm{C}$ night) in April and May, respectively, after 3 versus 4 months of chilling (containerized $Q$. macrocarpa stock plants required at least 4 months of chilling for uniform budbreak; data not shown). Stock plants were watered and shoots were removed, leaving a 4-cm-tall stump above the soil surface. To ensure maximum budbreak stock, plants in Expt. 2 were treated with gibberellic acid $\left(\mathrm{GA}_{(4+7)}, 500 \mathrm{mg} \cdot \mathrm{L}^{-1}\right.$ applied as a spray to runoff) repeated every fourth day until budbreak, which occurred 4 to $7 \mathrm{~d}$ after the plants were removed from the cooler. GA applications do not influence the percentage of rooting under these circumstances (data not shown).

Plants in both experiments were randomly assigned to two light treatments (etiolation and natural light) implemented at budbreak. Small and large caliper size plants were uniformly distributed among treatments. Stock plants in each light treatment were randomly assigned to three groups for age of stems at time of cutting (3, 6, and 9 weeks in Expt. 1; 3 and 6 weeks in Expt. 2). Upon budbreak, plants were etiolated (98\% light exclusion) or grown in natural light until shoots reached a height of $6 \mathrm{~cm}$, time zero for the age treatment. Upon reaching 6 $\mathrm{cm}$ in height, etiolated shoots were banded (half in Expt. 1 and all in Expt. 2; banding is a localized light exclusion treatment that excludes light from the portion of the stem to become the cutting base), and the top part of the new shoot was acclimated to ambient light over a period of 1 week. Half the shoots grown in natural light in Expt. 1 were banded. None of the shoots from the natural light treatment in Expt. 2 were banded. To further maintain uniformity and regulate growth by arresting elongation, shoots in all treatments had their apical buds removed when the shoot reached a height of $\approx 12 \mathrm{~cm}$, the height attained after $\approx 1$ week. This operation limited cuttings to approximately four nodes. At the end of each stem aging period, cuttings were taken by severing the shoot immediately proximal to the banded or equivalent area. Where necessary, green areas below the
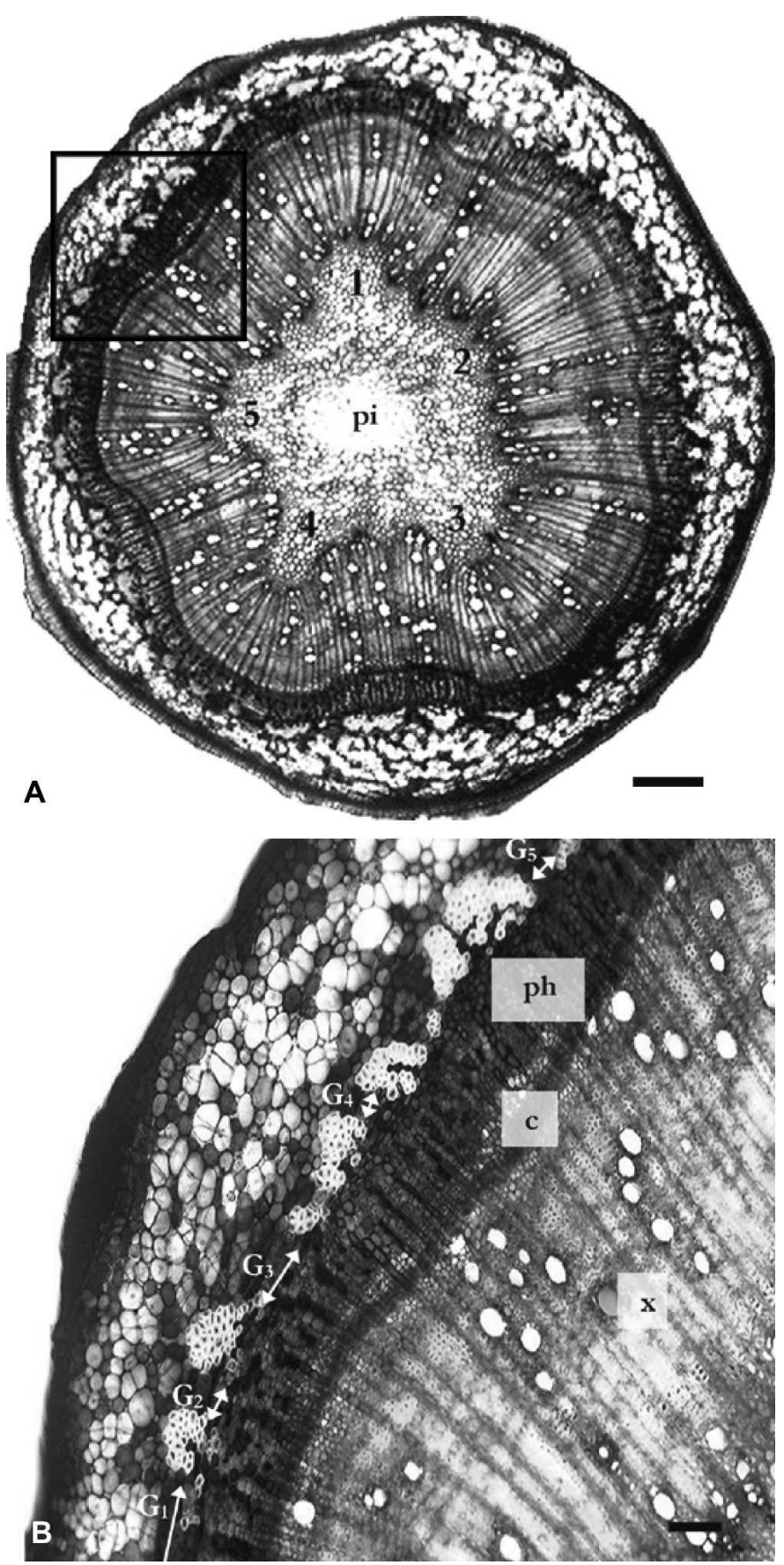

Fig. 1. Transverse section of the rooting zone of Quercus bicolor at the time of excision. (A) Entire transverse section. Numerals mark the five lobes of the pith (pi). Boxed region appears in $\mathbf{B}$ at higher magnification, illustrating gap measurement where parenchymatous gaps (G1, G2, etc.) alternate with fiber strands, the walls of which appear bright in the photograph. Secondary phloem (ph), secondary xylem (x), and vascular cambium (c) are present. Percentage of parenchymatous gap was calculated as $\left[\%=\right.$ sum of the lengths of $G_{i}$ (white arrows)/length of the inclusive circumferential arc $\times 100]$. Scale bars: $(\mathrm{A})$ $50 \mu \mathrm{m}$ and (B) $100 \mu \mathrm{m}$. 
Table 1. Effect of age of stem at time of cutting (3, 6, and 9 weeks) on the percentage of fiber-free (parenchymatous) gaps in the perivascular region of field-grown Quercus bicolor and Quercus macrocarpa (Expt. 1).

\begin{tabular}{lcc}
\hline $\begin{array}{l}\text { Age of stem at } \\
\text { cutting (weeks) }\end{array}$ & $\begin{array}{c}\text { Fiber-free } \\
\text { gap }(\%)^{\mathrm{z}}\end{array}$ & $\begin{array}{c}\text { Rooting } \\
(\%)^{\mathrm{y}}\end{array}$ \\
\hline $\begin{array}{l}\text { Q. bicolor } \\
3\end{array}$ & $26.8 \mathrm{a}^{\mathrm{x}}$ & $59.8 \mathrm{a}$ \\
6 & $9.8 \mathrm{~b}$ & $12.5 \mathrm{~b}$ \\
9 & $7.05 \mathrm{bc}$ & $4.6 \mathrm{c}$ \\
Q. macrocarpa & & \\
3 & $10.3 \mathrm{~b}$ & 0 \\
6 & $4.5 \mathrm{~cd}$ & 1.0 \\
9 & $2.3 \mathrm{~d}$ & 0
\end{tabular}

${ }^{\mathrm{z}_{\mathrm{n}}}=12$ stems per treatment duration per species.

${ }^{\mathrm{y}}$ Based on numerous cuttings in each category.

${ }^{x}$ Any two means within a column not followed by one or more letters in common are significantly different at $P \leq 0.05$ (least square means).

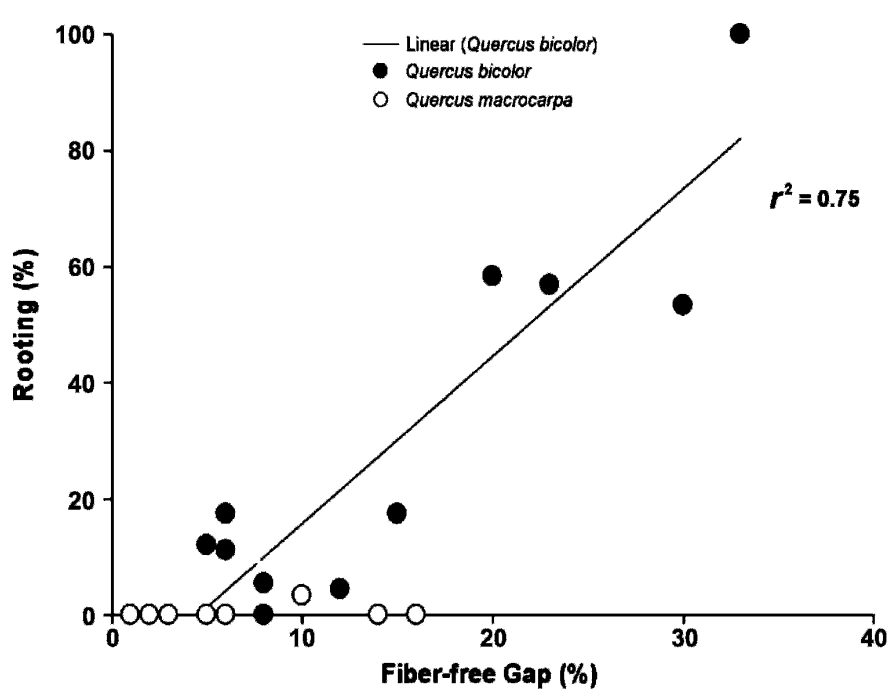

Fig. 2. Regression of percentage of rooting on percentage of fiber-free gap in the perivascular region of Quercus bicolor $(\bullet)$ and Quercus macrocarpa $(\bigcirc)$. Each point represents three replicates for a single treatment (species $\times$ light $\times$ age of stem at cutting). $\mathrm{n}=24$ (five pairs of points overlap). Significance level of correlation is $P<0.0001$.

banded region were removed so only etiolated tissue formed the cutting base.

A minimum of 15 cuttings per treatment (species $\times$ light $\times$ age at time of cutting) were set aside for scoring ( 4 weeks later) in Expt. 2. Each cutting had two leaves, larger leaves were trimmed to half their size, and the freshly cut stem bases were dipped in $6000 \mathrm{mg} \cdot \mathrm{L}^{-1}$ indole butyric acid (IBA) dissolved in $50 \%(\mathrm{v} / \mathrm{v})$ ethanol in water for $10 \mathrm{~s}$. After the IBA solution had dried, cuttings were stuck to a depth of $6 \mathrm{~cm}$ into $100 \%$ horticultural-grade perlite. Cuttings were rooted under intermittent mist (6 s every 8 min from 0600-2100 HR) and were shaded (65\% light exclusion). No rotting occurred during the rooting period.

EXPT. 1: EFFECTS OF SPECIES, AGE OF STEM AT TIME OF CUTTING, AND LIGHT TREATMENTS ON PERCENTAGE GAPS IN THE SCLERENCHYMA SHEATH. Two species ( $Q$. bicolor and $Q$. macrocarpa), four light treatments (light only, light + banding,
Table 2. Effect of light treatments and age of stem at time of cutting (3 and 6 weeks) on the percentage of rooting and the average number of roots per cutting of greenhouse-grown Quercus bicolor and Quercus macrocarpa cuttings (Expt. 2).

\begin{tabular}{|c|c|c|c|}
\hline & $\begin{array}{c}\text { Rooting } \\
(\%)\end{array}$ & $\begin{array}{c}\text { Roots } \\
\text { (no./cutting) }\end{array}$ & $\begin{array}{c}\text { Cuttings } \\
\text { (no./treatment) }\end{array}$ \\
\hline \multicolumn{4}{|l|}{ Q. bicolor } \\
\hline EB-3 weeks ${ }^{\mathrm{z}}$ & $85.3 \mathrm{a}^{\mathrm{y}}$ & $18.1 \mathrm{a}$ & 34 \\
\hline L-3 weeks & $65.7 \mathrm{bc}$ & $10.6 \mathrm{bc}$ & 35 \\
\hline EB-6 weeks & $74.0 \mathrm{abd}$ & 14.4 abe & 77 \\
\hline L-6 weeks & $51.9 \mathrm{c}$ & $10.3 \mathrm{bd}$ & 81 \\
\hline \multicolumn{4}{|l|}{ Q. macrocarpa } \\
\hline EB-3 weeks & $48.3 \mathrm{c}$ & $16.3 \mathrm{abc}$ & 29 \\
\hline L-3 weeks & $43.6 \mathrm{ce}$ & $10.7 \mathrm{abc}$ & 16 \\
\hline EB-6 weeks & $52.0 \mathrm{~cd}$ & $8.3 \mathrm{cde}$ & 25 \\
\hline L-6 weeks & $22.7 \mathrm{e}$ & $2.0 \mathrm{f}$ & 22 \\
\hline
\end{tabular}

$\overline{{ }^{\mathrm{z}} \mathrm{EB}}=$ Cuttings etiolated and banded; $\mathrm{L}=$ Cuttings grown in natural light; 3 and 6 weeks represent the age of stems at time of cutting and the duration of light treatments.

${ }^{\mathrm{y}}$ Any two means within a column not followed by one or more letters in common are significantly different at $P \leq 0.05$ (least square means).

etiolated only, etiolated + banding) and three age-of-stem treatments $(3,6$, and 9 weeks) were investigated. The basal $4 \mathrm{~cm}$ of five cuttings were harvested at random from among cuttings assigned to each treatment (species $\times$ light $\times$ age of stem) before IBA application. Stem segments were fixed in formalin:alcohol:glacial acetic acid (1:18:1 by volume) using $70 \%(\mathrm{v} / \mathrm{v})$ ethanol in water in the fixative and for storage after a minimum fixation of $3 \mathrm{~d}$. Hand sections were mounted on slides and stained with toluidine blue $\left(0.5 \mathrm{~g} \cdot \mathrm{L}^{-1}\right.$ in $0.1 \mathrm{M}$ acetate buffer, $\mathrm{pH} 4.4$ ) for $\approx 1 \mathrm{~min}$ and were then rinsed in distilled water. Transverse sections were photographed using a camera (DXC9000; Sony Corp., Tokyo) attached to an optical microscope (BX 60; Olympus Optical Co., Tokyo) under the control of a computer. Three of the five stems in each of the 24 treatments were sampled. Selection was based only on section quality and clarity of the recorded images. Measurements were made on transverse sections as circumferential arcs to obtain the percentage of parenchymatous versus sclerenchymatous tissue along the circumference of the pericyclic ring of fibers (Fig. 1, A and B). At the magnification used (20×), a measurement was compiled from photographs representing an arc distance of $50 \%$ of circumference.

EXPT. 2: The SEQUENCE OF EVENTS DURING ADVENTITIOUS ROOT DEVELOPMENT. The anatomy of stem segments during rooting was investigated to identify the sites of initiation of root primordia and to make a temporal record of the progress of adventitious root formation. Attention was given to whether the sclerenchyma sheath can be interpreted as a barrier to the initiation and emergence of adventitious roots. In addition, the zero-hour collection of shoots was examined anatomically to determine the percentage of parenchyma gap in the sclerenchyma ring, as in Expt. 1.

For the time course of root development, cuttings from each species were randomly assigned to treatments (light $\times$ age of stems at time of cutting). Five cuttings were harvested for anatomical study of the basal $4-\mathrm{cm}$-segment of each cutting immediately before IBA application (day 0 ) and on alternate days for $24 \mathrm{~d}$ after IBA application. The segments were fixed as in Expt. 1. Sixty-five stem pieces were examined for each of the 
eight treatments (light $\times$ age of stem at time of cutting $\times$ species). All stages of the time course received equal emphasis. Thin transverse hand sections of the rooting zone were made using razor blades. Sections were photographed as in Expt.1.

Statistical analysis. Anatomical data for the percentage of parenchyma gap in the sclerenchyma ring were analyzed using the PROC GLM procedure of SAS (release 9.1; SAS Institute, Cary, NC). Results of the percentage of the fiber-free gap in the sclerenchyma ring were arcsine transformed before analysis. Means separation was done using least square means. Data on rooting and number of roots per shoot for the root progression study (Expt. 2) were analyzed using binomial and negative binomial regression models (PROC GENMOD; SAS Institute), respectively. Means separation was done using least square means and a significance level of $P=0.05$.

\section{Results}

EXPT. 1: EFFECTS OF SPECIES, AGE AT TIME OF CUTTING, AND Light TREATMENTS ON PERCENTAGE GAPS IN THE SCLERENCHYMA SHEATH. For each age at time of cutting, a significantly lower percentage of parenchymatous gaps (thus, a greater proportion of phloem fibers) was found in the perivascular region of $Q$. macrocarpa compared with that of $Q$. bicolor (Table 1). Percentage rooting in $Q$. bicolor correlated well $\left(r^{2}=0.75\right)$ and varied directly with the percentage of fiber-free gaps in the perivascular region (Fig. 2). The percentage of fiber-free gaps decreased with increasing stem age and was significantly $(P<0.001)$ higher at 3 weeks than at 6 weeks or 9 weeks in both species (Table 1). The percentage of fiber-free gaps in $Q$. bicolor cuttings at week $6(9.8 \%)$ was indistinguishable from that in $Q$. macrocarpa cuttings at 3 weeks $(10.3 \%)$ and corresponded to poor rooting (Table 1). Light treatments had no significant effect $(P>0.05)$ on the percentage of parenchymatous gap in the perivascular region of either species (data not shown).

EXPT. 2: The SEQUence OF EVENTS DURING ADVENTITIOUS ROOT DEVELOPMENT. In this experiment, we used greenhouse-grown plants to obtain higher rooting percentages than were obtained with field-grown plants (compare Tables 1 and 2; see also Amissah, 2007), thereby providing sufficient materials to confirm that rooting in both species follows the same developmental course. Thus, the

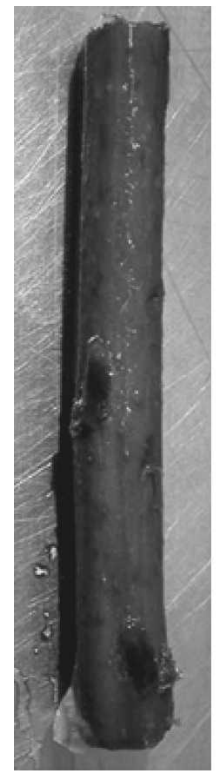

$4 \mathrm{~d}$

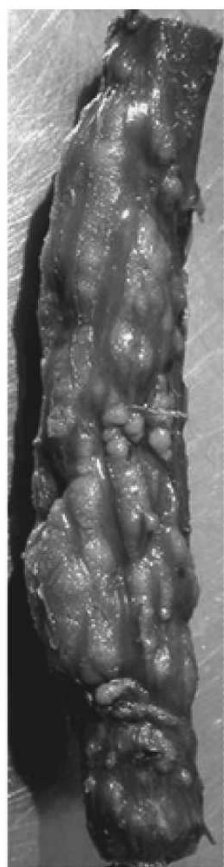

$16 \mathrm{~d}$ $\mathrm{mg} \cdot \mathrm{L}^{-1} \mathrm{IBA}$ descriptions given below apply to both species. Also, there was no significant difference for the percentage of parenchymatous gap in the sclerenchyma ring between the greenhouse-grown (Expt. 2) and the field-grown (Expt. 1) shoots for either species (data not shown; but see Discussion for further comment).

MACROSCOPIC APPEARANCE OF CUTTINGS THAT SUCCESSFULLY ROOTED. Ten days after cuttings were stuck, slight bulges were observed on the cutting base (Fig. 3). After $12 \mathrm{~d}$, cracks were noticed on the dermal layer. By $14 \mathrm{~d}$, bulging and cracking of the dermal layer had become more pronounced. Roots emerged as early as $14 \mathrm{~d}$ in some cuttings, but emergence generally

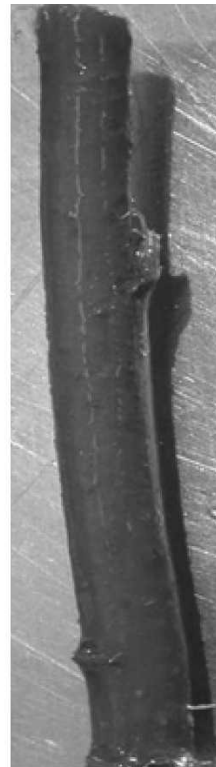

$6 d$

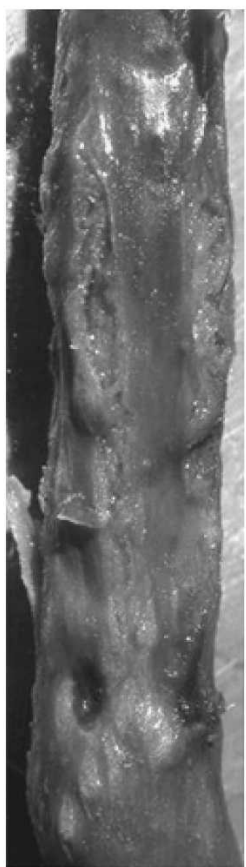

$18 d$

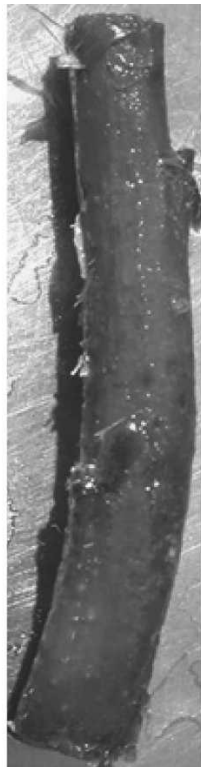

$8 d$

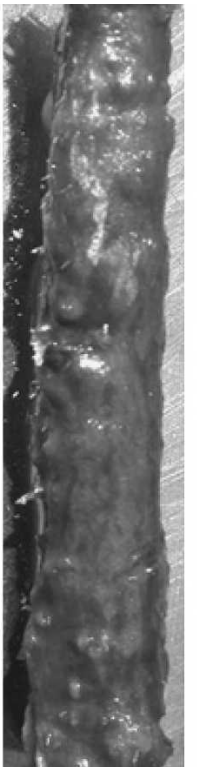

$10 \mathrm{~d}$

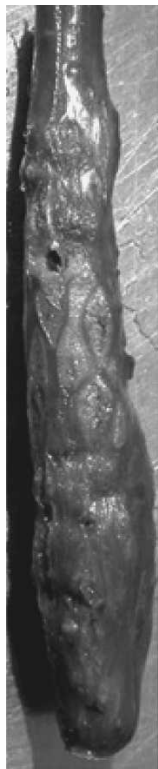

$12 \mathrm{~d}$

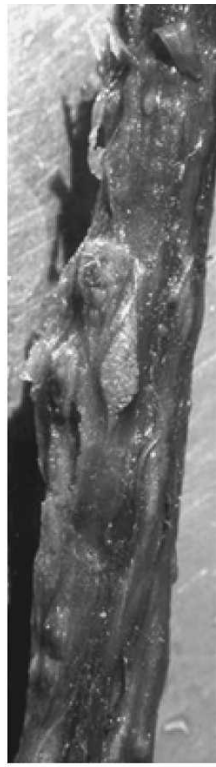

$14 d$

Fig. 3. Macroscopic appearance of bases of rooted cuttings of Quercus bicolor 4 to $24 \mathrm{~d}$ after applying 6000 

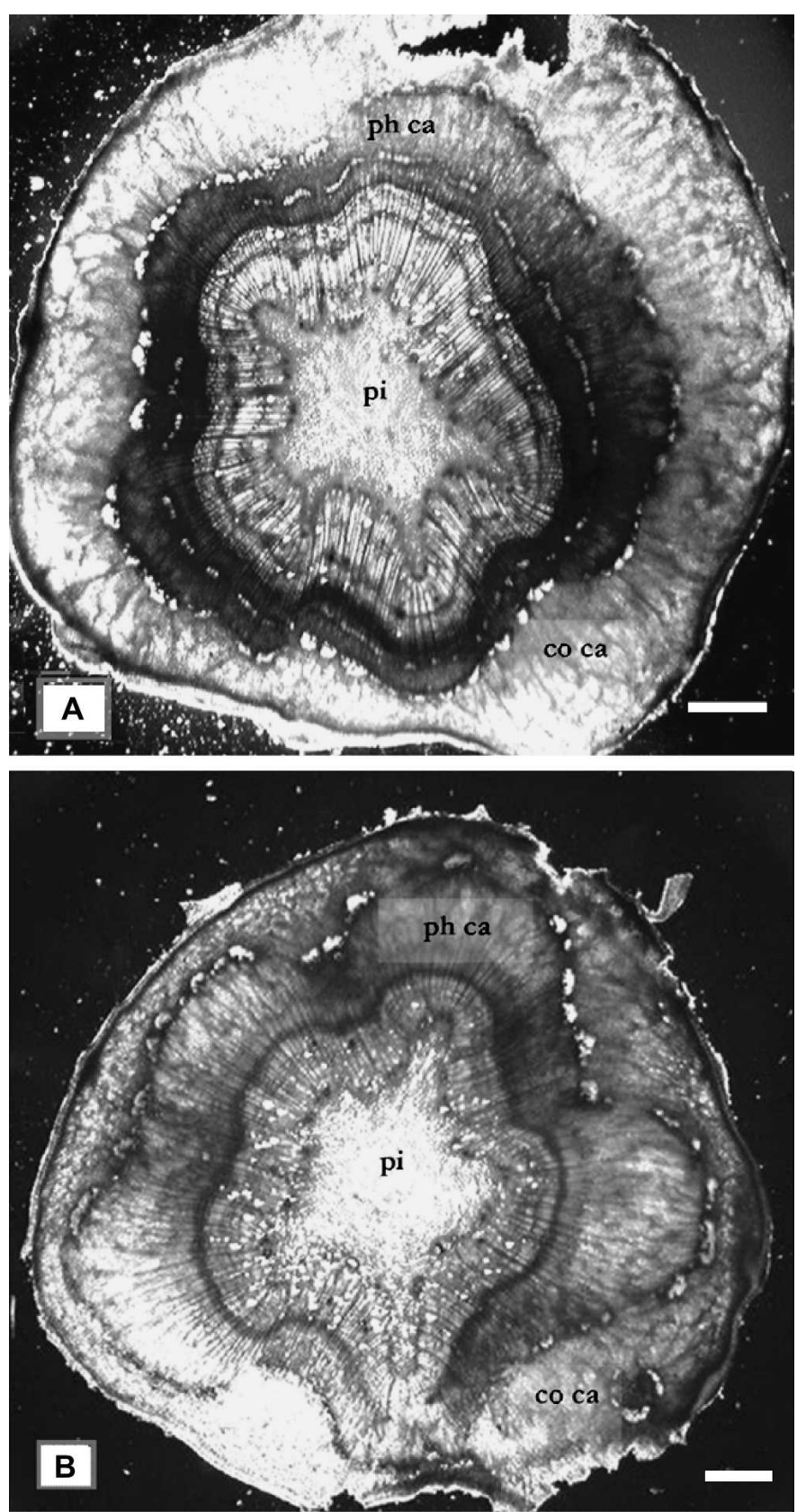

Fig. 4. Transverse sections of the rooting zone of Quercus bicolor showing response to application of $6000 \mathrm{mg} \cdot \mathrm{L}^{-1} \mathrm{IBA}$. (A) At $8 \mathrm{~d}$, callus occurred in the cortex (co ca) outside the sclerenchyma ring and to a lesser degree within the phloem (ph ca), inside the sclerenchyma ring. (B) At $12 \mathrm{~d}$, callus in the phloem region (ph ca) was more abundant than earlier. Callus within phloem was always located on the same radii as the lobes of the pith (pi). Scale bars = $50 \mu \mathrm{m}$.

occurred by 18 to $24 \mathrm{~d}$. The young roots were white, 0.3 to $0.5 \mathrm{~mm}$ thick, and devoid of root hairs. Roots formed as close as $1 \mathrm{~mm}$ from the base of the cutting and were arranged in longitudinal rows along the stem (Fig. 3).

Алатомy of cuttings. The description is presented for stems as seen in the transverse section. Untreated cuttings showed the normal stem organization of an epidermis with the early stages of phellem formation, cortex, and a ring of closely arranged vascular bundles that had progressed into the formation of secondary vascular tissue with a sinuous outline (Fig.
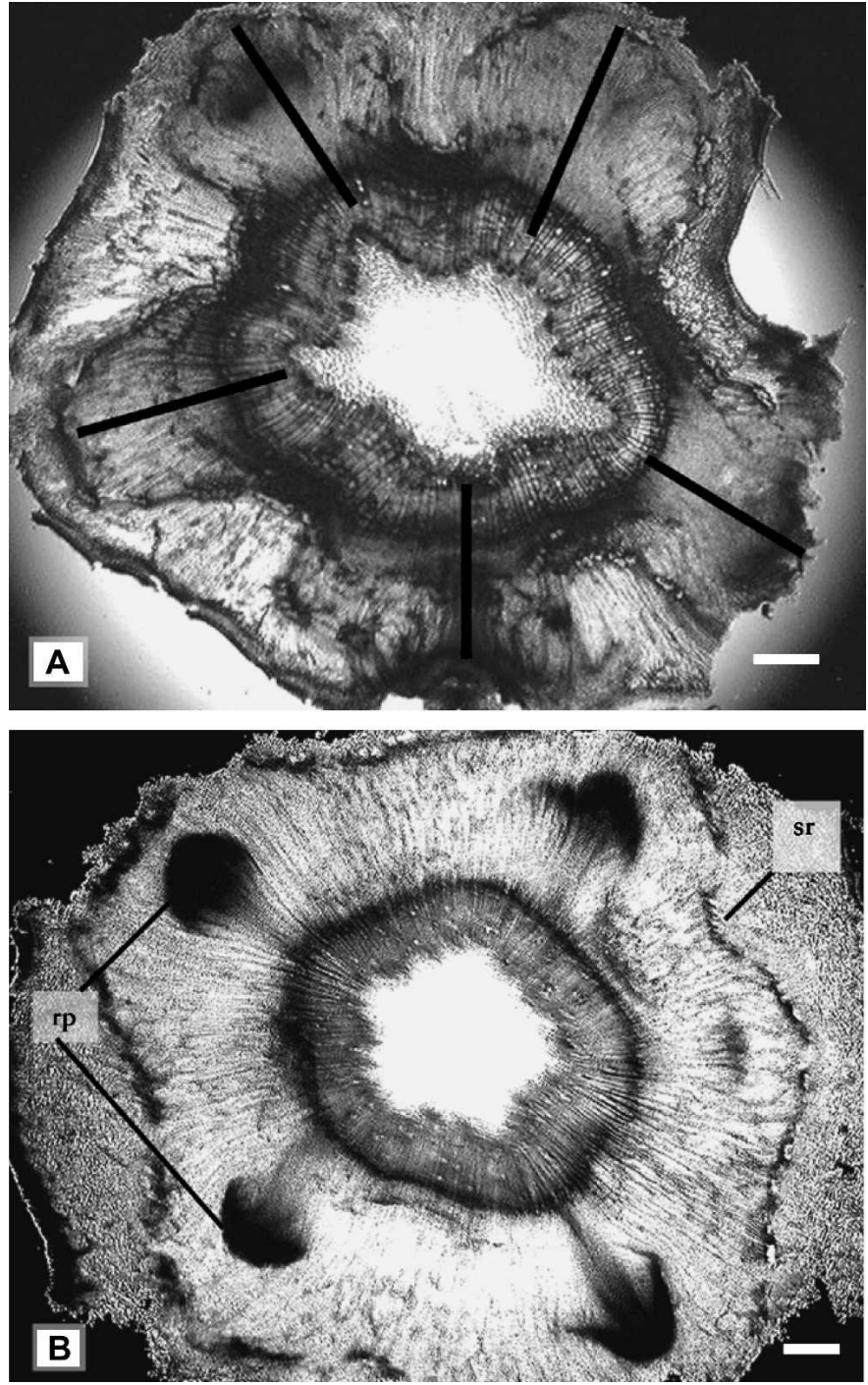

Fig. 5. Transverse sections of Quercus bicolor $14 \mathrm{~d}$ after application of 6000 $\mathrm{mg} \cdot \mathrm{L}^{-1}$ IBA. (A) Proliferation in the phloem exceeded that in the cortex so that bulging of the entire stem structure occurred directly opposite the five lobes of the pith (on radii indicated by black lines). (B) Proliferation in the secondary phloem was coordinated with the location of the root primordia (rp). The sclerenchyma ring (sr) was much displaced by proliferation in the phloem. Scale bars $=50 \mu \mathrm{m}$.

1A). There was a distinct five-lobed pith (Fig. 1A) with lobes extending into the area of the vascular tissue that curved outward, accounting for the sinuous outline of the vascular cylinder. These configurations were interpreted as manifestations of leaf arrangement along the stem, the lobes of the pith being extensions of closed leaf gaps into the third dimension (Esau, 1965), and their exact forms being a function of the proximity of the nearest leaf attachment on a particular radius. The phloem was surrounded by a discontinuous ring of sclerenchyma, formed by groups of phloem fibers (strands in three dimensions) separated laterally by small areas of parenchyma cells (Fig. 1B), the parenchymatous gaps. The stem anatomies of $Q$. macrocarpa and $Q$. bicolor were qualitatively similar with regard to cell types and tissue organization.

No detectable anatomical changes were observed the first $6 \mathrm{~d}$ after IBA application. Eight days after cuttings were placed in the rooting medium, somewhat irregular cell proliferation 
(callus) was observed in the cortex, peripheral to the phloem fiber bundles and on radii between the pith lobes (Fig. 4A). By 8 to $12 \mathrm{~d}$, significant callus growth was detected in the phloem region, centripetal to the fiber bundles, on radii coincident with the lobes of the pith (Fig. 4, A and B). Proliferations in the secondary phloem eventually superseded in extent those in the cortex (Fig. 5A). The extensive proliferation in the phloem opposite lobes of the pith was coincident with the eventual locations of root primordia (Fig. 5B). By $12 \mathrm{~d}$, root initials had formed within the proliferative tissue at these locations (Fig. 6A), in the secondary phloem at some distance from the cambium. By 14 to $16 \mathrm{~d}$, the root primordia had developed, each acquiring a dome-shaped apex with a differentiated root cap (Fig. 6B) and, subsequently, vascular differentiation (Fig. 6C). Each primordium that grew outward crushed the cells adjacent to the root cap, and forced its way between fiber strands, displacing them laterally (Fig. 6, D and E). By $18 \mathrm{~d}$, some roots had emerged and most primordia had reached the outer cortex, attended by progressive differentiation of their vascular systems. By $24 \mathrm{~d}$ after application of IBA, short roots had emerged through splits in the epidermis in successful cuttings (Fig. 7, B and D). By the time of root emergence, fully matured vascular connections had been established between the vascular systems of the adventitious roots and that of the cutting (Fig. 7, A and C).

In contrast to the proliferation external to the cambium, expansion of the secondary xylem was not detectable during the course of this experiment. No significant expansion
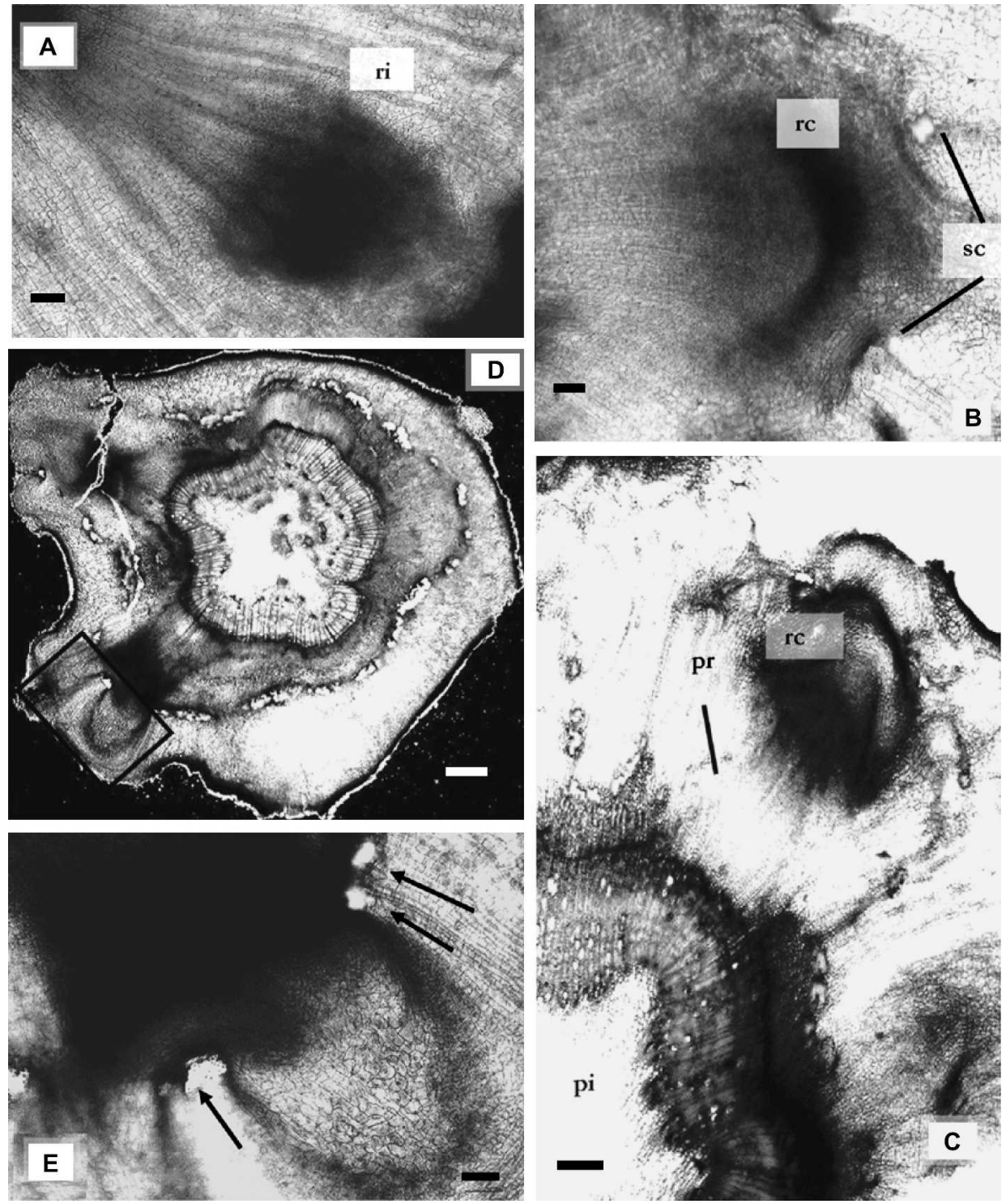

Fig. 6. Details of root initiation and growth in Quercus bicolor, A to C, and Quercus macrocarpa, D and E. All figures are from transverse sections of the cuttings. Times given are from application of $6000 \mathrm{mg} \cdot \mathrm{L}^{-1} \mathrm{IBA}$. (A) At $12 \mathrm{~d}$, showing root initial (ri). (B) At $16 \mathrm{~d}$, showing an organized root primordium with an apical meristem and root cap (rc). Growth of the root was beginning to separate fiber bundles (sc) that were once more nearly adjacent. (C) At $14 \mathrm{~d}$, showing protruding root primordium opposite lobe of pith (pi). Procambium (pr) and root cap (rc) were differentiated in the root. (D) Off-median section of root primordium protruding between bundles of phloem fibers. Area within box is enlarged in $\mathbf{E}$ to show fiber bundles (arrows). Scale bars: A to $\mathrm{C}=100 \mu \mathrm{m}$, $\mathrm{D}=50 \mu \mathrm{m}$, and $\mathrm{E}=12 \mu \mathrm{m}$
$(P>0.05)$ of the xylem cylinder in either species was found over time during rooting (data not shown).

\section{Discussion}

To the best of our knowledge, this study is the first to outline the root development sequence in oak cuttings. Here, we apply our results to an analysis of the relationship of stem anatomy to the success of the rooting process.

Our results indicate an association between the percentage gap within the ring of pericyclic fibers seen in transverse sections and the relative success of the rooting process. The percentage of rooting correlated well with the percentage of parenchymatous gap in the perivascular fiber ring of $Q$. bicolor cuttings (Fig. 2). Furthermore, Q. bicolor cuttings had a significantly higher percentage gap in the sclerenchyma sheath compared with cuttings of $Q$. macrocarpa, where the percentage gap was generally low and coincided with the low percentage rooting (Table 1). Doud and Carlson (1977) also observed a negative correlation between the percentage of sclerification and rooting in Malus rootstocks. In the present study, the percentage of parenchymatous gap decreased with stem age at the time of cutting in both species of Quercus. A simultaneous decrease in rooting ability was demonstrated for Q. bicolor (Table 1).

Because a ring of fibers in the transverse section represents a net in the third dimension, a greater frequency of sclerenchyma in the transverse section probably means that the sheath formed 


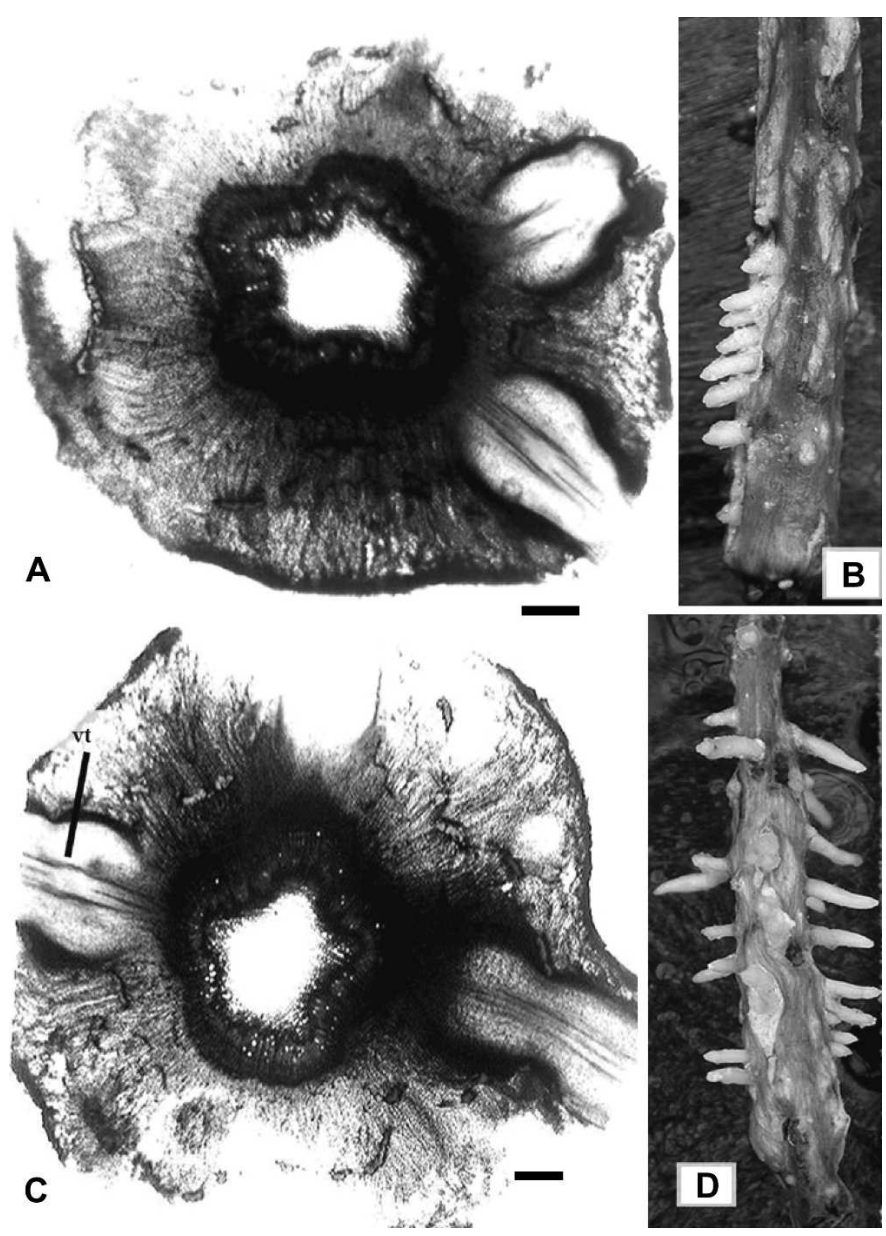

Fig. 7. Root emergence in Quercus bicolor. Times given are from application of $6000 \mathrm{mg} \cdot \mathrm{L}^{-1}$ IBA. (A) At $24 \mathrm{~d}$, showing complete differentiation of the root vascular system of the root by the time of root emergence. (B) Rooted cutting at $20 \mathrm{~d}$. Roots line up vertically along stem. (C) At $24 \mathrm{~d}$, vascular system of lateral root (vt) with mature conducting cells was connected to the vascular system of the cutting. (D) Cutting at $24 \mathrm{~d}$ showing multiple lines of root primordia. Scale bars: $\mathrm{A}$ and $\mathrm{C}=50 \mu \mathrm{m}$. Stem diameter in $\mathrm{B}$ and $\mathrm{D}=0.5 \mathrm{~cm}$.

by the net is more coherent. A coherent network of fibers could physically restrain cell expansion and proliferation, which, as observed in the present study, are required for root primordia to form in oak stems. However, treating the correlation between the percentage gap in the pericyclic fibers and rooting as a causal relationship has serious problems. In the greenhousegrown plants of Expt. 2, the percentage of rooting of $Q$. bicolor and $Q$. macrocarpa was much higher than in the field-grown plants of Expt. 1. However, comparing the cuttings in the two experiments, there was no significant difference in the percentage of parenchyma gap in the fiber ring for either species, suggesting that other factors controlled the increased rooting. The relationships that suggest cause and effect are likely to be associated with other physiological and anatomical conditions that are permissive of rooting. Rooting is a process that must advance through successive stages (Lovell and White, 1986) and as such, proliferative activity at the sites of root initiation must occur before roots can be organized. Changes of this kind have physiological as well as anatomical prerequisites.

Moreover, stem anatomy in $Q$. bicolor and $Q$. macrocarpa were qualitatively the same, and the developmental stages seen for adventitious root formation for the two species were also the same. Two stages of cell proliferation, each leading to radial expansion, were observed in both species of oak. The first stage occurred in the cortex peripheral to the phloem fiber bundles, on radii between the pith lobes. The second expansion occurred within the secondary phloem, on the same radii as the pith lobes. Roots originated only in proliferative tissue within secondary phloem. In cuttings that did not root, only the first stage of expansion occurred, to a lesser extent than was observed in cuttings that rooted.

In a study of six Acacia baileyana F. Muell. genotypes, Schwarz et al. (1999) showed that roots were initiated in internal callus and that all genotypes under study had similar stem anatomies, whereas the ability to form adventitious roots varied with genotype. Lovell and White (1984), in their examination of $G$. littoralis and $G$. lucida cuttings, saw the lack of root initiation sites as a more likely reason for low rooting than the presence of a sclerenchyma sheath acting as a barrier to root emergence. Davies and Hartmann (1988) suggested that the inability of woody cuttings to root may result from the failure, for physiological reasons, of parenchymatous cells to dedifferentiate into cells capable of forming root primordia. Lovell and White (1986) suggested that a cutting may fail to root because essential anatomical events fail to occur, even if potential root initiation sites exist, or anatomical changes may result only in vascular development and not in the development of root primordia. In some cases, the commitment of cells to the formation of sclerenchyma precludes their becoming root initials (Maynard and Bassuk, 1996), thereby reducing the potential for rooting.

Overall, rooting in $Q$. bicolor was significantly better than that in $Q$. macrocarpa, and $Q$. macrocarpa had the greater development of sclerenchyma. But given the reservations on the role of sclerenchyma mentioned above, we favor the conclusion that reduced rooting in $Q$. macrocarpa is more a result of the inability of cuttings to form primordia or a prevention of the cell expansion and proliferation required for rooting rather than a result of mechanical restrictions of the growth of root primordia by the sclerenchyma ring. Like Davies et al. (1982), we favor the conclusion that the difference in rooting here under study is more related to the ease of adventitious root initiation than to restrictions on root emergence. Once formed, root primordia penetrated the parenchymatic discontinuities between the groups of phloem fibers, the fiber strands being displaced apart as the roots emerged. Although the fiber sheath may have played some role in preventing the necessary expansion and proliferation needed for root initials to form, predominantly in $Q$. macrocarpa, one remains free to speculate that the quantitative anatomical differences between species simply reflect physiological differences that control anatomical details and the ability for cell proliferation. Thus, the correlations between the percentage of gap and rooting found in this study may depend on the relationship of both parameters to causal factors in rooting, or more specifically, the physiological circumstances that promote rooting also promote parenchyma cell differentiation in the pericyclic region.

\section{Literature Cited}

Amissah, J.N. 2007. Effect of juvenility and etiolation on clonal propagation of Quercus species. Ph.D. Diss. Cornell University, Ithaca, NY. 
Barlow, H.W.B., C.R. Hancock, and H.J. Lacey. 1961. Some biological characteristics of an inhibitor extracted from woody shoots. Proc. 4th Int. Conf. Plant Growth Regulat. p. 127-140.

Beakbane, B. 1961. Structure of the plant stem in relation to adventitious rooting. Nature 192:954-955.

Beakbane, B. 1969. Relationships between structure and adventitious rooting. Combined Proc. Int. Plant Propagators Soc. 19:192-201.

Ciampi, C. and R. Gellini. 1958. Anatomical study of the relationship between structure and rooting capacity in olive cuttings. Nuovo Giornale Botanico Italiano 65:417-424.

Davies, F.T., Jr. and H.T. Hartmann. 1988. The physiological basis of adventitious root formation. Acta Hort. 227:113-120.

Davies, F.T., Jr., J.E. Lazarte, and J.N. Joiner. 1982. Initiation and development of roots in juvenile and mature leaf bud cuttings of Ficus pumila L. Amer. J. Bot. 69:804-811.

Doud, S.L. and R.F. Carlson. 1977. Effect of etiolation, stem anatomy and starch reserves on root initiation of layered Malus clones. J. Amer. Soc. Hort. Sci. 102:487-491.

Edwards, R.A. and M.B. Thomas. 1980. Observations on physical barriers to root formation in cuttings. Plant Prop. 26:6-8.

Esau, K. 1965. Plant anatomy. 2nd ed. Wiley, New York.

Goodin, J.R. 1965. Anatomical changes associated with juvenile-tomature growth phase transition in Hedera. Nature 208:504-505.

Herman, D.E. and C.E. Hess. 1963. The effect of etiolation upon the rooting of cuttings. Combined Proc. Int. Plant Prop. Soc. 13:42-62.

Hess, C.E. 1961. A comparative analysis of root initiation in easy and difficult to root cuttings. Plant Physiol. 36 (Suppl.):XXI (Abstr.).

Hicks, R.R. and W.T. Gladstone. 1971. Some anatomical aspects of rooting quaking aspen. Proc. 11th Southern Forest Tree Improvement Conf. p. 265-274.

Lovell, P.H. and J. White. 1984. Factors influencing adventitious root production in cuttings of Griselina littoralis and Griselina lucida. Ann. Bot. (Lond.) 53:443-446.

Lovell, P.H. and J. White. 1986. Anatomical changes during adventitious root formation, p. 111-139. In: M.B. Jacksons (ed.). New root formation in plants and cuttings. Martinus Nijhoff, Dordrecht, The Netherlands.

Mahlstede, J.P. and D.P. Watson. 1952. An anatomical study of adventitious root development in stems of Vaccinium corymbosum. Bot. Gaz. 113:279-285.
Maynard, B.K. and N.L. Bassuk. 1992. Stock plant etiolation, shading and banding effects on cutting propagation of Carpinus betulus. J. Amer. Soc. Hort. Sci. 117:740-744.

Maynard, B.K. and N.L. Bassuk. 1996. Effect of stock plant etiolation, shading, banding, and shoot development on histology and cutting propagation of Carpinus betulus L. fastigiata. J. Amer. Soc. Hort. Sci. 121:853-860.

Ooyama, N. 1962. Studies on promotion of rooting ability of the cuttings from tree species difficult to root (in Japanese with English summary). Govt. For. Expt. Sta. Meguro, Tokyo, Bul. No. 145.

Priestley, J.H. 1926. Problems of vegetative propagation. J. Royal Hort. Soc. 51(1):1-16.

Raviv, M., D. Becker, and Y. Sahali. 1986. The chemical identification of root promoters extracted from avocado tissues. Plant Growth Regulat. 4:371-374.

Reańo, P.C. 1940. Histological study and observations on the effect of some synthetic growth substances on stem tip cuttings of coffee. Philippine Agriculturist 29:87-99.

Reid, O. 1923. The propagation of camphor by stem cuttings. Trans. Bot. Soc. Edinburgh 28:184-188.

Sachs, R.M., F. Loreti, and J. DeBie. 1964. Plant rooting studies indicate sclerenchyma tissue is not a restricting factor. California Agr. 18(9):4-5.

Schwarz, J.L., P.L. Glocke, and M. Sedgley. 1999. Adventitious root formation in Acacia baileyana F. Muell. J. Hort. Sci. Biotechnol. 74(5):561-565.

Smith, E.P. 1924. The anatomy and propagation of clematis. Trans. Proc. Bot. Soc. Edinburgh 29(1):17-26.

Stangler, B.B. 1956. Origin and development of adventitious roots in stem cuttings of chrysanthemum, carnation and rose. Cornell Univ. Agr. Expt. Sta. Memoirs 342:1-24.

Stoutemeyer, V.T. 1961. Light and propagation. Combined Proc. Int. Plant Prop. Soc. 11:252-260.

White, J. and P.H. Lovell. 1984. The anatomy of root initiation in cuttings of Griselinia littoralis and Griselinia lucida. Ann. Bot. (Lond.) 54:7-20.

William, R.R., A.M. Taiji, and J.A. Bolton. 1984. Suberization and adventitious rooting in Australian plants. Aust. J. Bot. 32:363366. 